\title{
"Let the business cycle!" A spatial multilevel analysis of cycling to work
}

Thomas Vanoutrive, Laurent Van Malderen, Bart Jourquin, Isabelle Thomas, Ann Verhetsel and Frank Witlox

\section{(2) OpenEdition}

Journals

\section{Electronic version}

URL: http://journals.openedition.org/belgeo/8763

DOI: 10.4000/belgeo.8763

ISSN: 2294-9135

\section{Publisher:}

National Committee of Geography of Belgium, Société Royale Belge de Géographie

\section{Printed version}

Date of publication: 30 June 2009

Number of pages: 217-232

ISSN: 1377-2368

\section{Electronic reference}

Thomas Vanoutrive, Laurent Van Malderen, Bart Jourquin, Isabelle Thomas, Ann Verhetsel and Frank Witlox, " "Let the business cycle!" A spatial multilevel analysis of cycling to work», Belgeo [Online],

2 | 2009, Online since 21 May 2013, connection on 20 April 2019. URL : http://

journals.openedition.org/belgeo/8763; DOI : 10.4000/belgeo.8763

This text was automatically generated on 20 April 2019.

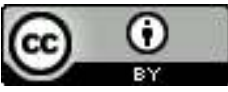

Belgeo est mis à disposition selon les termes de la licence Creative Commons Attribution 4.0 International. 


\title{
"Let the business cycle!" A spatial multilevel analysis of cycling to work
}

\author{
Thomas Vanoutrive, Laurent Van Malderen, Bart Jourquin, Isabelle \\ Thomas, Ann Verhetsel and Frank Witlox
}

\section{Introduction}

1 The daily commute is still the main source of traffic congestion due to its repeated and concentrated character. This concentration of traffic in both space (cities) and time (peak hours) makes commuting the prime target of mobility policies. The overall aim of such policies is a reduction of the number of Single Occupant Vehicles (SOVs). In Belgium, $66,4 \%$ of the workforce commutes as a car driver (Verhetsel et al., 2007). The SOValternatives are carpooling, telework, public transport and the bicycle, the latter being the subject of this paper.

2 Substantial spatial variation exists in bicycle use, not only between countries but also within countries. The share of commuter cyclists in Belgian municipalities varies between zero and $21,7 \%$ with a mean of 4,6 \% (Vandenbulcke et al., 2009b). To explain bicycle use, the literature refers to physical, individual, environmental and policy factors (see recent review in Vandenbulcke et al. 2009b). The most important physical features are topography (slopes) and meteorological conditions (rainfall and wind speed). The second group contains more individual factors like car ownership, journey distance, journey purpose, income, education, bicycle ownership, class, age and concerns for health and the environment. Environmental factors, as a third group, are related to the urban spatial structure. Examples are population density, land-use mix, city size, traffic volume and infrastructure characteristics. The last category of policy-related variables covers infrastructure, transport and land-use policies of different government agencies as well as financial incentives and education (Comsis Corporation, 1993; Rodriguez and Joo, 2004; Parkin et al., 2007; Vandenbulcke et al., 2009b). Martens (2004) notes huge differences in cycling cultures between European countries, however cultural differences are usually a 
synonym for unexplained variance without appointing the cultural attributes that matters.

3 The focus of commuting and SOV-alternatives research is mainly on the individual commuter (e.g. Cao and Moktharian, 2005) or on the county (e.g. Zahran et al., 2008) or municipality level (e.g. Vandenbulcke et al., 2009a and 2009b; Rietveld and Daniel, 2004) while less attention goes towards the work side of the home to work travel. However, employers influence the commute behaviour of their employees in many ways. It is known from literature that firm location, work schedules and mobility management initiatives have a significant impact on travel behaviour (Abbes-Orabi and De Wolf, 2007; Heinen et al., 2008; Van Malderen et al., 2009). The results reported here deal with the role employers play in the travel behaviour of their employees. The central topic is the bicycle as main commuting mode, and particular attention goes towards the measures that employers take to promote this mode. Indeed, many employers are willing to tackle environmental, congestion and recruiting problems by using mobility management strategies. Such strategies and plans are also called "green commuter plans" (GCP), "green transport plans" or "employer (based) transport plans" (Rye, 1999). However, such measures tend to tackle the symptoms (provide cycle facilities) but fail to tackle the underlying problems (distance, complex trip characteristics, etc.). Therefore questions raised about the number of employees that could be reached with mobility management measures since only a minority of commuters puts the bicycle in their choice set (Dickinson et al., 2003).

4 We here use a spatial multilevel regression model to incorporate both site-specific and contextual factors. Since bicycle use is not randomly distributed in space, the multilevel structure is also used to deal with spatial autocorrelation and to counterbalance the violation of the normality and independence assumptions. Finally, multilevel modelling using different spatial levels gives insight in the spatial structure of bicycle use.

5 The paper is structured as follows. First we introduce the database Home-to-Work-Traffic (HTWT) and give an overview of the selected variables. This is followed by a short discussion on the incorporation of space in regression models and the reasons why we chose for spatial multilevel modelling. Next the results are given together with a discussion, especially on the unexpected results. Finally, we end with some conclusions.

\section{Data and Methods}

\section{The Home-to-Work-Traffic Database}

6 For decades, census data are the main source for research on commuting (Dickinson, 1957; Verhetsel et al., 2007). Following a Belgian law of 2003 a new important data source is available about home-to-work displacements of employees. This new data source is based on a three-yearly questionnaire on mobility management initiatives of large companies. The first questionnaire dates from 2005 and needed to be filled in by every company with at least 100 employees for every site with at least 30 employees. This questionnaire differs from censuses and commute diaries in the sense that employers are the respondents and information about sustainable commuting measures is delivered. The questionnaire needed to be discussed in the works council in order to control the data and to deliver a base for a debate on mobility management in companies. 
7 Table 1 shows the frequencies of the 15 bicycle promoting measures that could be indicated in the questionnaire. The most popular bicycle-incentives are a bicycle fee and some common bicycle facilities, like storage. The database Home-to-Work-Traffic (HTWT) contains also the Crossroads Bank for Enterprises (CBE) code for each company. With this code we identified the economic sector (Nacebel 2003) using the BELFirst database. Table 2 shows both the average percentage of cyclists and the average number of bicycle promoting measures per economic sector. The "divers government" category are worksites which could not be linked to a Nacebel code. This category contains different kinds of government agencies like police stations, public schools and municipal offices. Cycling seems to be popular at schools and workplaces of governments, while the financial sector has the lowest average share of bicycle use, despite the higher number of bicycle-promoting initiatives.

Table1. Frequency of the bicycle mobility management measures on worksites.

\begin{tabular}{|llr|}
\hline Type of measure & Description of measure & Frequency (\%) \\
\hline Financial & additional cycling fee & 42,76 \\
& additional fee for work trips & 7,18 \\
\hline Bicycle facilities & covered bicycle storage & 34,85 \\
& secured bicycle storage & 28,74 \\
& showers & 24,12 \\
& room to change clothes & 23,35 \\
& bicycle repair facilities & 3,06 \\
& improvement of infrastructure & 2,90 \\
& rain clothes & 1,61 \\
\hline Provision of & bicycles available for work trips & 9,20 \\
bicycles & bicycle maintenance & 1,27 \\
& bicycles available for home-to-work travel & 0,84 \\
& bicycles available at the railway station & 0,64 \\
\hline Other and & other & 7,29 \\
information & information on cycling routes & 2,88 \\
\hline
\end{tabular}

Source : 2005 questionnaire HTWT ; $n=7460$ 
Table 2. Bicycle mobility management measures and bicycle use per economic sector.

\begin{tabular}{|lccr|}
\hline Economic sector (Nacebel 2003) & $\begin{array}{c}\text { average } \\
\text { number of } \\
\text { bicycle } \\
\text { measures }\end{array}$ & $\begin{array}{c}\text { average } \\
\text { percentage of } \\
\text { cycling } \\
\text { employees }\end{array}$ & \# observations \\
\hline Agriculture, hunting, forestry and fishing (AB) & 2,08 & 8,78 & 12 \\
Mining and quarrying (C) & 2,25 & 5,24 & 12 \\
Manufacturing (D) & 1,99 & 7,48 & 1092 \\
Electricity, gas and water (E) & 1,58 & 3,58 & 111 \\
Construction (F) & 2,14 & 3,04 & 108 \\
Wholesale and retail; repair of motor vehicles & 1,67 & 5,01 & 875 \\
and consumer goods (G) & 1,69 & 5,02 & 86 \\
Hotels and restaurants (H) & 1,04 & 8,40 & 587 \\
Transport, warehousing and communication & 2,62 & 2,44 & 182 \\
(I) & 1,50 & 3,27 & 469 \\
Finance (J) & & & \\
Real estate, renting and producer services (K) & 2,94 & 4,90 & 18 \\
Public administration and defence; social & 2,18 & 12,34 & 136 \\
security insurance (L) & 1,81 & 5,52 & 231 \\
Education (M) & & & \\
Health and social services (N) & 1,70 & 6,03 & 96 \\
Other community, social and personal & 2,11 & 11,92 & 3445 \\
services (O) & & & \\
Divers Government (Z) & & & \\
\hline
\end{tabular}

Source : 2005 questionnaire HTWT ; $\mathrm{n}=7460$

\section{Variables}

8 Table 3 shows the list of selected variables. The dependent variable $(\mathrm{Y})$ is the percentage of employees at a worksite making use of the bicycle as main transport mode for their daily commute. Most worksites have a low share of cyclists in the modal split and as a result, the assumption of a normal distribution is violated and therefore the Y-variable is transformed into $\operatorname{lnY} /(1-\mathrm{Y})$ (Luke, 2004). On 1844 of the 7460 worksites there are no employees which use the bicycle as main mode for commuting $(\mathrm{Y}=0)$. This is another important violation of the normality assumption and therefore the zero observations are excluded from the main model. A binary logistic regression (noted Logit) is made to compare the excluded with the observations included in the main model. 
Table 3. List of variables.

\begin{tabular}{|c|c|c|c|c|c|}
\hline \multicolumn{6}{|c|}{ variables measured at the worksite level } \\
\hline variable & description & source & $\min$ & $\max$ & \\
\hline$y$ & $\begin{array}{l}\% \text { employees using bicycle as } \\
\text { main commute mode }\end{array}$ & HTWT database 2005 & $-6,91$ & 2,63 & $\ln y /(1-y)$ \\
\hline LogEmploy & \# employees & HTWT database 2005 & 1,48 & 3,82 & logarithm \\
\hline LogFixed & $\begin{array}{l}\% \text { employees with fixed work } \\
\text { schedule }\end{array}$ & HTWT database 2005 & $-1,3$ & 2 & logarithm \\
\hline ParkingIndex & car parking/employee & HTWT database 2005 & 0 & 1 & \\
\hline Train<1 km & railway station at less than $1 \mathrm{~km}$ & HTWT database 2005 & 0 & 1 & binary \\
\hline $\mathrm{MTB}<500 \mathrm{~m}$ & $\begin{array}{l}\text { metro/tram/bus-stop within } \\
500 \mathrm{~m}\end{array}$ & HTWT database 2005 & 0 & 1 & binary \\
\hline DummyCEF & economic sector CEF (2005) & BELFirst & 0 & 1 & binary \\
\hline DummyD & economic sector D (2005) & BELFirst & 0 & 1 & binary \\
\hline DummyG & economic sector G (2005) & BELFirst & 0 & 1 & binary \\
\hline DummyJK & economic sector JK (2005) & BELFirst & 0 & 1 & binary \\
\hline DummyM & economic sector M (2005) & BELFirst & 0 & 1 & binary \\
\hline Dummyz & economic sector Z (2005) & BELFirst & 0 & 1 & binary \\
\hline Provision & \# 'bicycle provision' measures & HTWT database 2005 & 0 & 4 & \\
\hline Facilities & \# bicycle facilities & HTWT database 2005 & 0 & 7 & \\
\hline Financial & \# 'financial' measures & HTWT database 2005 & 0 & 2 & \\
\hline BicyParking & bicycle parking/employee & HTWT database 2005 & 0 & 1 & \\
\hline \multicolumn{6}{|c|}{ variables measured at the municipality level } \\
\hline variable & description & source & $\min$ & $\max$ & \\
\hline LogSlope & $\begin{array}{l}\text { average slope on the roads in } \\
\text { the municipality }\end{array}$ & $\begin{array}{l}\text { Vandenbulcke et al. } 2008 \text { and } \\
2009 b\end{array}$ & $-0,16$ & 1 & logarithm \\
\hline LogJobDens & $\begin{array}{l}\text { job density: \# jobs/inhabitants } \\
\text { age 20-64 (2005) }\end{array}$ & $\begin{array}{l}\text { HTWT database } 2005 \text {; FPS } \\
\text { Economy-Directorate-general } \\
\text { Statistics Belgium }\end{array}$ & $-2,4$ & 0,13 & logarithm \\
\hline $\log 2024$ & $\%$ population age $20-24(2005)$ & $\begin{array}{l}\text { FPS Economy-Directorate-general } \\
\text { Statistics Belgium }\end{array}$ & $-1,4$ & $-1,05$ & logarithm \\
\hline FamChild & $\begin{array}{l}\% \text { families with children }<6 \\
(2005)\end{array}$ & $\begin{array}{l}\text { FPS Economy-Directorate-general } \\
\text { Statistics Belgium }\end{array}$ & 0,1 & 0,36 & \\
\hline
\end{tabular}

9 Figure 1 shows the average share of cycling on a worksite, aggregated per municipality. A clear north-south pattern appears with high values in the north and low values in the south. To drill deeper into this spatial pattern, a LISA map (Anselin, 1995; Figure 2) is produced to detect spatial clusters and outliers. This exploratory map challenges the common subdivision of Belgium based on a presumed Flemish cycling culture in the north, and the lack of such culture in the French-speaking (or Walloon) part of Belgium. Undoubtedly, the spatial variance in cycling originates from other factors, like commuting distance and topography, which spatial pattern better fits with that of our dependent variable. Indeed, the southern part of Flanders is no part of the spatial cluster of municipalities with high values surrounded by similar municipalities (high-high cluster), and in the north-eastern and north-western parts of the Walloon region cycling is more popular than in the rest of that region. 
Figure 1. Average share of cycling employees in Belgian municipalities.

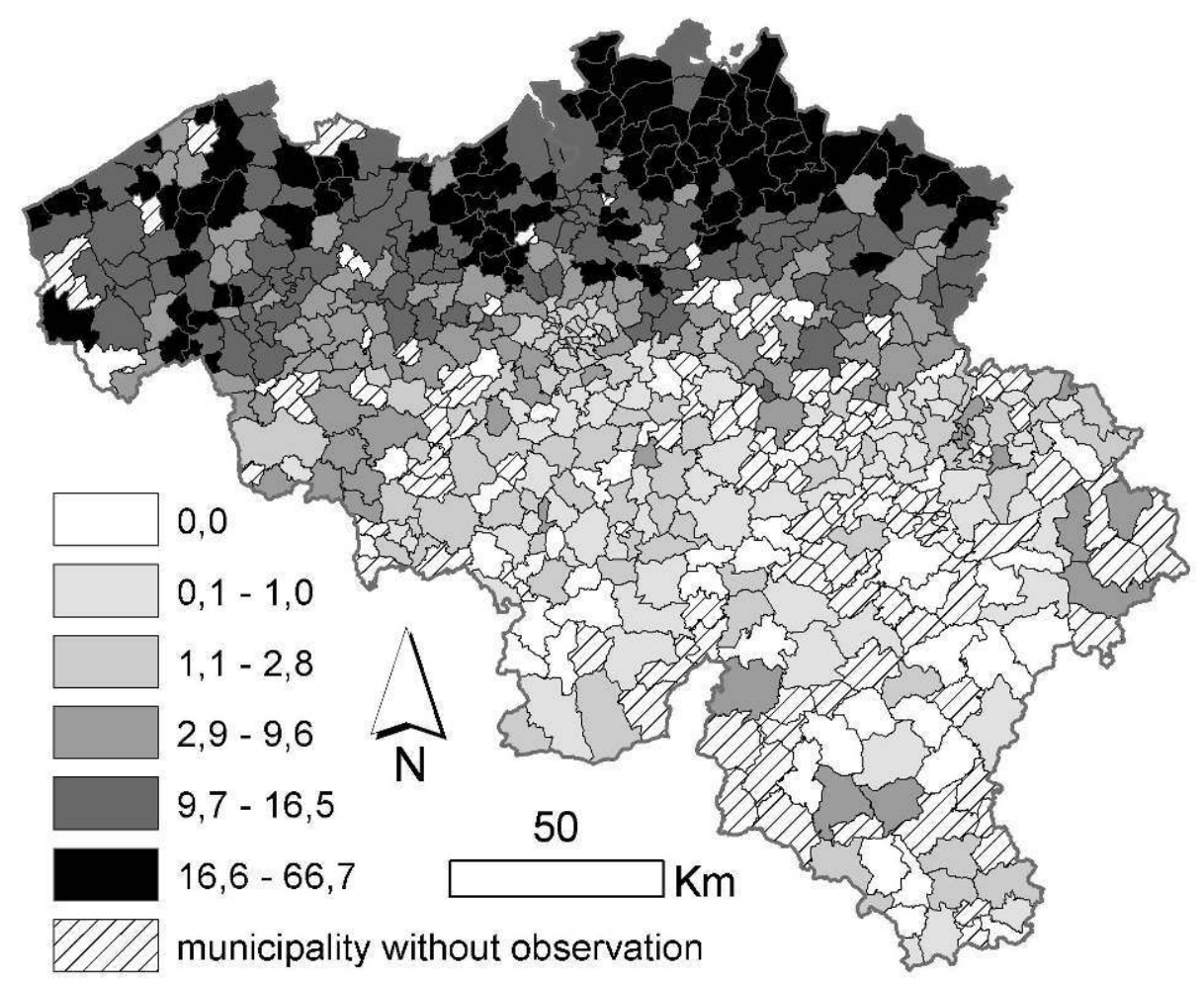

SOURCE: DATABASE HTWT 2005 
Figure 2. LISA cluster map of cycling employees in Belgian municipalities taking into account the 4 nearest neighbouring municipalities (LISA: Local Indicators of Spatial Association; Anselin, 1995).

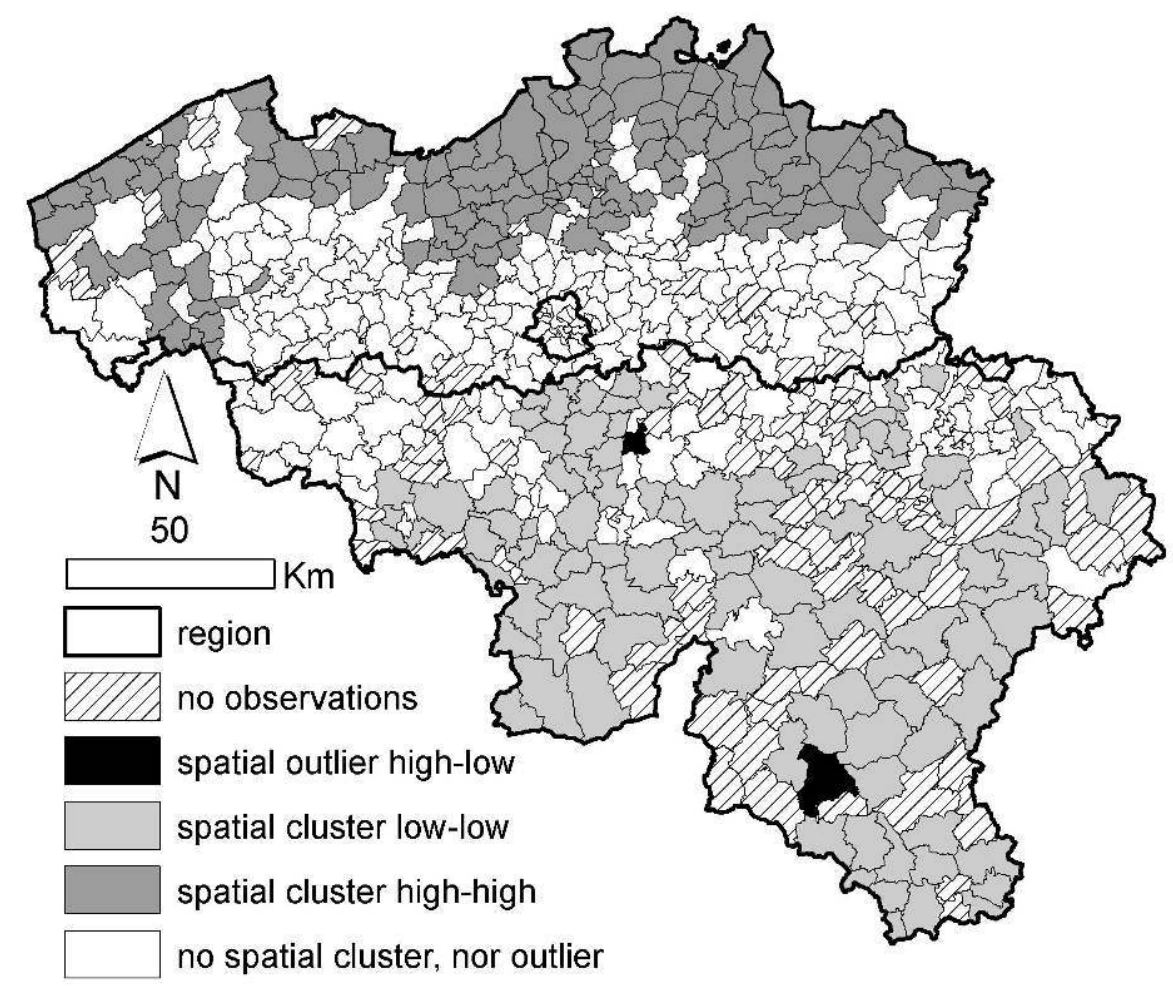

SOURCE: DATABASE HTWT 2005

We now will describe the explanatory variables in Table 3. Size is a first characteristic of a worksite. Sites with more employees have in general more possibilities for collective transport and a longer average commuting distance. Parking is another important mode choice determinant. A lack of parking space is often cited as one of the most important reasons for the popularity of SOV-alternatives (Naess and Sandberg, 1996; Banister and Gallent, 1999; Potter et al., 1999; Ferguson, 2000). Therefore the number of parking places per employee is included in the model. The maximum value of this parking index is limited to 1 to avoid the effect of large customer parking. SOV-alternatives, other than cycling, can also affect the success of the bicycle. Therefore, the accessibility by public transport is modelled using dummy variables indicating a metro, tram or bus stop or a railway station within respectively $500 \mathrm{~m}$ and $1 \mathrm{~km}$.

Work regimes have a large impact on the activity and travel patterns of employees (Abbes-Orabi and De Wolf, 2007; Heinen et al., 2008). The proportion of the workforce with a fixed work schedule is used as variable. Mode choice depends also on the economic sector. The economic sectors given in Table 2 are grouped to obtain a set of dummy variables. Only sectors or groups of sectors with more than 100 observations are maintained. One of the major shortcomings of the database HTWT is the lack of information on company cars. However, company cars and free parking are the most important incentives for not choosing SOV-alternatives (Kingham et al., 2001; O'Fallon et al., 2004). The economic sector variables will pick up some of the company car effect, nevertheless for a straightforward estimation data at the workplace level should be available. 
The first is a geostatistics approach, which defines space as a continuous surface. In our case however, observations are not continuous but discrete objects. Moreover, a geostatistics approach easily changes into a black box with difficulties to explain the rationale behind the imposed spatial structure. The second approach uses an object view and the corresponding lattice model. In this case, a spatial structure is imposed using a spatial weights matrix that underlies a spatial process model. This is the so-called spatial econometric approach and the LISA map in Figure 2 is an exploratory application of this method. The most distinctive characteristic is the incorporation of the value of neighbouring observations. The third way to impose a spatial structure is the spatial error components approach, as used in spatial multilevel modelling. In a random intercept multilevel regression model there is not only a residual at the lowest level (worksite, $\left.e_{i j}\right)$ but also at the municipality level $\left(u_{\mathrm{oj}}\right)$. More formally, this can be written as :

$\mathrm{y}_{\mathrm{ij}}=\beta_{0 \mathrm{j}}+\beta_{1} \mathrm{x}_{\mathrm{ij}}+\mathrm{e}_{\mathrm{ij}}(1)$

$\beta_{0 j}=\beta_{0}+u_{0 j}(2)$

with $\mathrm{i}=$ worksite level and $\mathrm{j}=$ municipality level.

This model allows that different level-2 units have different intercepts (and this is therefore called random intercept model). The $\mathrm{u} 0 \mathrm{j}$-terms are the level-2 random effects 
or the level-2 residuals. Multilevel modelling not only has the advantage of getting a better understanding and more clear interpretation of the effects of higher (spatial) levels, but ignoring the fact that data are grouped can also cause underestimated standard errors of regression coefficients (Goldstein, 1995; Maas and Hox, 2004; Schwanen et al., 2004; Rasbash et al., 2005). The main disadvantage is that models become more complex. As a consequence, diagnostics can be more complicated.

17 Multilevel modelling is increasingly used to incorporate contextual factors in regressions and to investigate the role of higher geographical scales. Examples can be found in health (e.g. Langford et al., 1998), housing market (e.g. Orford, 2000) and commuting research (e.g. Schwanen et al., 2004). A multilevel structure enables us to incorporate both variables at the worksite level and at the municipality level in a statistically correct way. A related advantage is that different levels (scales) can be modelled simultaneously (Subramanian et al., 2001). Since our dataset consists of individual workplaces and we do not want to ignore the municipality level, the use of a spatial multilevel model is preferred over a spatial econometrics approach (for a more in-depth comparison between spatial multilevel modelling and spatial econometrics: see Vanoutrive and Parenti (2009)). However, cycling is still spatially autocorrelated at the municipality level. When grouping the data at the municipality level and using a spatial weights matrix using the four nearest neighbours, a Moran's I of 0,72 is found for the Y-variable. This measure indicates significant spatial autocorrelation as expected from Figures 1 and 2. Indeed, neighbouring municipalities often share similar characteristics and as a result, similar proportions of cyclists. Next to this, commuters can cycle to a neighbouring municipality. In our multilevel model, workplaces are nested in municipalities and next to variables at the worksite level, also variables at this municipality level are used. An underlying assumption is that the majority of potential cyclists lives in the same municipality as where they work. To relax this assumption, we add a third level: the arrondissement. Doing this, the population characteristics not only of the municipality, but also of the arrondissement are taken into account. We thus assume that a majority of the cyclists does not leave the own municipality, and if they do, they go to a municipality in the same arrondissement. The 43 Belgian arrondissements are in the first place administrative units, nevertheless in most cases they consist of a central city surrounded by less urbanised municipalities. A more functional spatial division, like labour basins (e.g. De Wasseige et al. 2000) is less appropriate in this case for two reasons. First, the division of Belgium in labour basins is particularly based on longer commutes and on other modes than the bicycle. Second, labour basins are far from equal. Indeed, the labour basin of Brussels dominates, together with those of some other large cities. No less than $27 \%$ of the workplaces are located in the Brussels labour basin, and 17\% in the second largest, Antwerp. Arrondissements on the other hand, divide Belgium in a more regular way. Summarising, the model deals with the spatial autocorrelation by means of its three-level structure.

\section{Results}

Table 4 shows the results of four multilevel models. The first model is a logit model (noted Logit) which compares the data included (1) and excluded (0) in the next three models. The excluded observations are the 1844 worksites without cycling employees. The next model, Model A, contains only a constant and a three-level structure while in 
model B all variables are included except variables which measure the degree of mobility management. Finally, Model C includes all variables.

Table 4. Results of the four multilevel models (Software = MLwiN).

\begin{tabular}{|c|c|c|c|c|c|c|c|c|c|}
\hline \multirow{4}{*}{$\begin{array}{l}\text { Random } \\
\text { part }\end{array}$} & & \multicolumn{2}{|c|}{ Logit } & \multicolumn{2}{|c|}{ Model A } & \multicolumn{2}{|c|}{ Model B } & \multicolumn{2}{|c|}{ Model C } \\
\hline & & Estimate & $\begin{array}{l}\text { Standard. } \\
\text { Error }\end{array}$ & Est. & S.E. & Est. & S.E. & Est. & S.E. \\
\hline & & & & & & & & & \\
\hline & level 3 & 0,660 & 0,162 & 0,968 & 0,221 & 0,405 & 0,095 & 0,345 & 0,082 \\
\hline & level 2 & 0,001 & 0,017 & 0,117 & 0,017 & 0,068 & 0,012 & 0,061 & 0,011 \\
\hline & level 1 & - & - & 0,880 & 0,017 & 0,707 & 0,014 & 0,687 & 0,013 \\
\hline \multicolumn{10}{|l|}{ Fixed part } \\
\hline constant & constant & 1,401 & 1,358 & $-2,921$ & 0,154 & 0,916 & 0,863 & 0,668 & 0,834 \\
\hline \multirow{5}{*}{$\begin{array}{l}\overline{\bar{\alpha}} \\
\underline{\vec{\Phi}}\end{array}$} & LogEmploy & 1,883 & 0,095 & & & $-0,500$ & 0,031 & $-0,436$ & 0,031 \\
\hline & LogFixed & 0,125 & 0,022 & & & 0,053 & 0,009 & 0,052 & 0,009 \\
\hline & ParkingIndex & $-0,330$ & 0,086 & & & $-0,413$ & 0,036 & $-0,481$ & 0,036 \\
\hline & Train $<1 \mathrm{~km}$ & 0,040 & 0,064 & & & 0,053 & 0,026 & 0,045 & 0,025 \\
\hline & MTB $<500 \mathrm{~m}$ & $-0,069$ & 0,097 & & & 0,147 & 0,037 & 0,116 & 0,037 \\
\hline \multirow{4}{*}{$\begin{array}{l}\frac{N}{\Phi} \\
\stackrel{\alpha}{\underline{\omega}}\end{array}$} & LogSlope & $-2,235$ & 0,289 & & & $-1,260$ & 0,183 & $-1,252$ & 0,176 \\
\hline & LogJobDens & $-0,131$ & 0,103 & & & $-0,233$ & 0,063 & $-0,233$ & 0,061 \\
\hline & Log2024 & 1,948 & 0,993 & & & 1,720 & 0,627 & 1,626 & 0,606 \\
\hline & FamChild & $-6,590$ & 1,518 & & & $-3,600$ & 1,114 & $-3,546$ & 1,070 \\
\hline \multirow{6}{*}{ 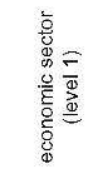 } & DummyCEF & $-0,544$ & 0,166 & & & $-0,441$ & 0,083 & $-0,419$ & 0,082 \\
\hline & DummyD & 0,221 & 0,117 & & & $-0,036$ & 0,046 & $-0,038$ & 0,045 \\
\hline & DummyG & 0,301 & 0,111 & & & $-0,047$ & 0,051 & $-0,049$ & 0,050 \\
\hline & DummyJK & $-0,016$ & 0,118 & & & $-0,311$ & 0,055 & $-0,323$ & 0,054 \\
\hline & DummyM & 1,018 & 0,264 & & & 0,458 & 0,086 & 0,319 & 0,086 \\
\hline & Dummyz & 0,796 & 0,087 & & & 0,438 & 0,037 & 0,369 & 0,037 \\
\hline \multirow{5}{*}{ 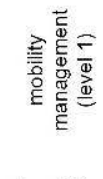 } & Provision & & & & & & & 0,127 & 0,030 \\
\hline & Facilities & & & & & & & $-0,019$ & 0,008 \\
\hline & Financial & & & & & & & 0,009 & 0,020 \\
\hline & BicyParking & & & & & & & 0,683 & 0,055 \\
\hline & -2 loglikelihood & & & 15667,23 & & 14356,97 & & 14180,27 & \\
\hline $\mathrm{n}$ level 3 & arrondissement & 43 & & 43 & & 43 & & 43 & \\
\hline n level 2 & municipality & 490 & & 442 & & 442 & & 442 & \\
\hline $\mathrm{n}$ level 1 & worksite & 7460 & & 5616 & & 5616 & & 5616 & \\
\hline
\end{tabular}

The random part of the model shows the variance at each hierarchical level. The Variance Partition Coefficient (VPC ; Rasbash et al., 2005) compares these variances, and indicates which percentage of the total variance can be attributed to a certain hierarchical level. Model A shows that only $6 \%(0,117 /(0,968+0,117+0,880))$ of the total variance may be attributed to differences between municipalities, but $49 \%$ to differences between "arrondissements" and $45 \%$ to the worksite level. The worksite level also covers the variance between individuals (Tranmer and Steel, 2001), for which no data was available. The fixed part of the model estimates the variables measured at the worksite and at the municipality level. Worksites with less employees, a higher proportion of staff with a fixed work schedule, less parking places per employee and more public transport facilities in the neighbourhood are associated with a higher proportion of cycling. The logit model shows that logically, the probability that there is at least one cycling employee is higher on a large site (more employees).

Differences between economic sectors appear to be relevant. When comparing the order of economic sectors in Table 2 with the results of model B, the sectors finance, real estate, renting and producer services are no longer at the bottom of the list, the lowest estimate is now for construction, electricity, gas and water and mining and quarrying. The top position is still for government-related sectors and education. At the municipality level, hilliness has a negative effect on cycling as have locations in an area with a high job density. A higher proportion of young active people (age 20-24) and a lower proportion of families with young children (age 0-5) are associated with more commuters who use the bicycle as main transport mode. 
Model C contains also four variables related to mobility management initiatives at the worksite. A positive relation appeared between the provision of bicycles and the number of cycling employees. However, for the bicycle facilities parameter the model estimated a negative significant result. For financial measures which promote the bicycle there is only a positive result when we leave out the economic sector variables. Finally, a positive relation is found with the number of bicycle parking places.

\section{Discussion}

The use of a spatial multilevel model made it possible to incorporate contextual factors in a statistically correct way and to investigate the role of different spatial scales. Up to $49 \%$ of the total variance can here be attributed to the arrondissement level and only $6 \%$ to the municipality level. These results suggest the limited importance of analyzing the data at the municipality level. However, municipal policies are probably spatially autocorrelated as well, and as a result, more important than the result notes. About $45 \%$ of the variance in bicycle use between worksites can be attributed to the worksite level. But one should notice that the worksite level covers also relevant differences between individual employees like gender, age and income (Heinen et al., 2008).

Worksites with many employees are associated with less bicycle use. This can easily be explained by the fact that large worksites might be quite isolated from urban centers and hence the average commuting distance is larger, and that there are more possibilities for collective transport. Less car parking places are traditionally seen as an important incentive for alternatives to car use. More employees with a fixed work schedule have also a positive effect on bicycle use as such a regular work regime fits better with cycling than for instance shifts.

Public transport facilities in the neighbourhood of the worksite are associated with more cycling commuters. These facilities are commonly linked with more dense areas, but the model estimated a negative result for job density. A lower share of cyclers in large agglomerations but a larger share in regional and small cities can explain this result (Vandenbulcke, 2009a and b).

26 As expected, population characteristics like a higher share of young active people (20-24) and a lower share of families with young children, influence cycling in a positive way. As a side remark, we note that for these population characteristics, the model assumes that the majority of the employees lives and works in the same municipality, or at least in the same arrondissement. The importance of the relief is demonstrated by the lower percentage of cyclists in hilly areas. Less commuters cycle in the construction, electricity, gas and water, and mining and quarrying sectors. Research by Meersman et al. (1998) about the Belgian construction sector showed that due to the changing location of construction sites, collective transport and carpool are more popular, and cycling less. Cycling is also less common in the sectors finance, real estate, renting and producer services. The large offices of the financial sector are associated with locations near railway stations, company cars are more frequent and the image factor (dress code) is probably more important in this sector. The high estimate for education can be explained by the fact that schools are often locally based, less spatially concentrated and company cars are exceptional. 
The active provision of bicycles by employers seems to influence the proportion of cycling employees in a positive way. However, one may not forget that this kind of measures is rather rare as showed in Table 2. For the financial measures no significant result is obtained but when leaving out the economic sector variables there is a significant positive effect. The "Additional cycling fee" is a result of the collective bargaining process which is subdivided in parity committees, which are to a certain extent related to economic sectors. The financial measures variable is as a consequence related to the economic sector variables.

Table 5. Frequencies of the number of bicycle facility measures on a worksite ( $n=5616)$.

\begin{tabular}{|l|l|l|l|}
\hline \# measures & frequency & $\%$ & $\begin{array}{l}\text { average \% } \\
\text { cycling employees }\end{array}$ \\
\hline 0 & 2596 & 46,23 & 11,07 \\
\hline 1 & 1100 & 19,59 & 12,70 \\
\hline 2 & 656 & 11,68 & 13,20 \\
\hline 3 & 630 & 11,22 & 11,65 \\
\hline 4 & 499 & 8,89 & 10,26 \\
\hline 5 & 111 & 1,98 & 11,62 \\
\hline 6 & 21 & 0,37 & 10,03 \\
\hline 7 & 3 & 0,05 & 6,63 \\
\hline
\end{tabular}

The negative result for bicycle facilities at a worksite is somewhat surprising. A first important remark is that regression models do not assume nor estimate a causal relationship. The potential simultaneity between measures and cyclists, i.e. only employers of sites where employees do cycle invest in facilities, is covered by omitting workplaces without cycling employees. But a closer look at the surprising result remains useful. A random slope model which allows a different slope for every municipality and/ or arrondissement does not change the loglikelihood and is as a consequence not useful to explore the bicycle facilities variable (Rasbash et al., 2005). Therefore a polynomial regression is made (Figure 3). The graph shows a positive effect until the number of measures is equal to 2 and then a decline. A seeming outlier effect could not be confirmed since leaving out the three observations with seven measures does not change the result. The estimate for three measures is still above the estimate for zero measures. Considering that $78 \%$ of the worksites take less than three measures and $89 \%$ of the worksites less than four, the negative result can be modified. 
Figure 3. Estimated bicycle use versus the number of bicycle facility measures.

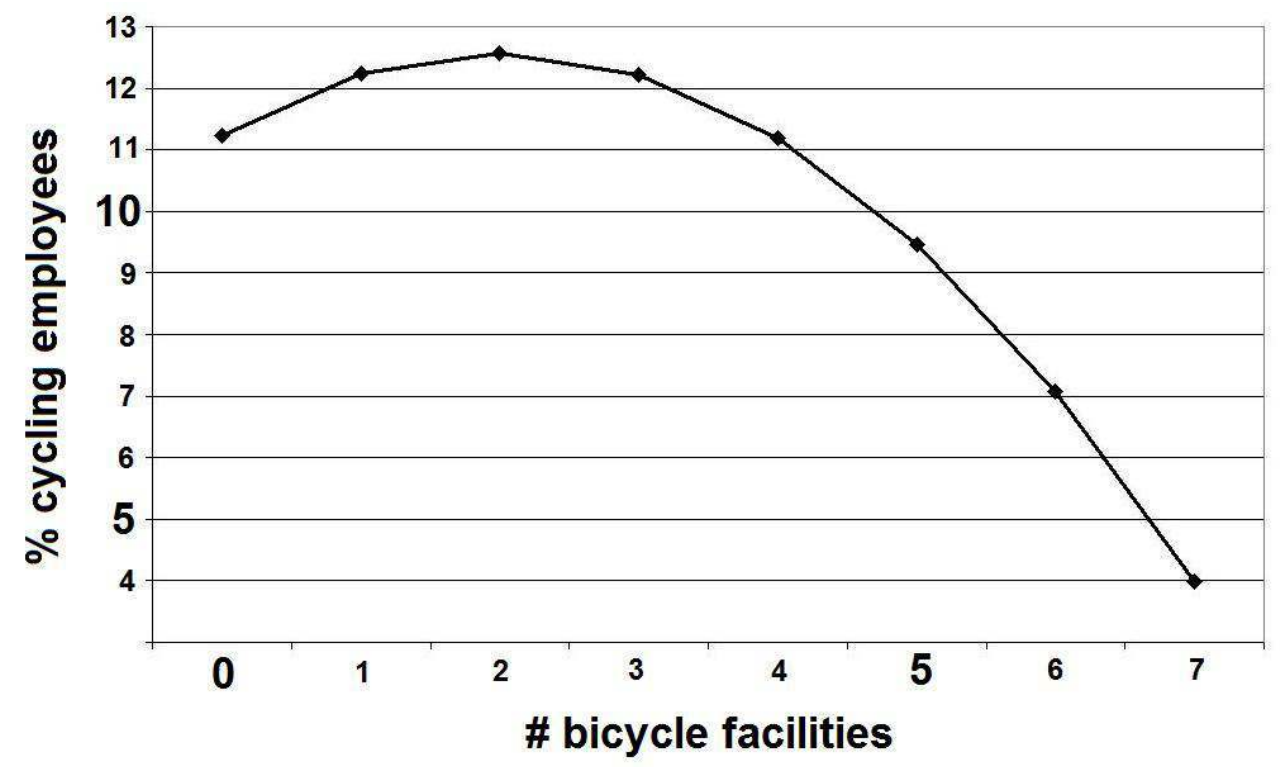

The common focus on cycling infrastructure neglects other aspects of cycling. Cycle facilities often just tackle the symptoms but do not affect underlying cycling discouraging factors like commute distance and complex trip characteristics. Facilities in the first place help to stabilise existing levels of bicycle use, less than they attract new bicycle users (Dickinson et al. 2003 ; Heinen et al., 2008 ; Cupples and Ridley, 2008).

Next to this, only employees which use the bicycle as main transport mode are considered in this analysis. The bicycle is however also an important mode for the travel between public transport stops and the worksite (Martens, 2004), but the impact of bicycle promoting measures on public transport use is outside the scope of this paper. Employers also often invest in transport-related measures for non mobility-related reasons. To filter out these potential effects, more in-depth case study research is necessary.

Finally, bicycle facilities are cheaper to implement on large sites outside city centres which are less attractive for cyclists, due to the longer travel distance. The urban fringe is overrepresented in the group of worksites with more than three bicycle facilities. Also the positive correlation between the number of bicycle facilities and the number of car parkings per employee seems to prove this assumption (Pearson correlation : 0,11). And it is definitely not a bad thing that employers invest more in facilities on sites which are less attractive for cyclists.

\section{Conclusion}

The work end of home-to-work travel is often not taken fully into account. The Belgian Home-to-Work-Traffic (HTWT) database now offers the opportunity to use a large database which contains information on accessibility, work regimes and mobility management initiatives of large employers located in Belgium. At the worksite level unsurprisingly, less employees, more fixed work schedules and less parking space per employee are positively related to the share of cycling employees. Significant differences exist between economic sectors, with less cycling employees in the construction, 
electricity, gas and water, and finance, real estate, renting and producer services sectors and more cyclists in government-related sectors, including education. The model controlled also for contextual factors like hilliness, job density and household characteristics, all measured at the municipality level.

The provision of bicycles by the employer and similar mobility management initiatives are positively related to the share of cycling employees. However, workplaces which offer several cycling facilities often have a lower share of cyclists. The main reason seems to be that bicycle facilities are easier to implement at large industrial sites outside agglomerations, which are less accessible by bike. Next to this, a focus on cycle infrastructure and facilities neglects other distinctive factors like commuting distance and trip complexity and can therefore in the first place be described as a treatment of the symptoms. Due to the large dataset, the results are a good reference for the evaluation of case studies. But it is obvious that more detailed data are necessary for the evaluation of mobility management initiatives at a particular site. For a better understanding of the effectiveness of mobility management programmes, case study research thus remains necessary.

Finally, spatial multilevel modelling proved to be a proper technique to incorporate both contextual and worksite level factors into a regression model, to explore the role of different spatial scale levels and to counterbalance spatial autocorrelation.

Acknowledgements

This research is conducted within the ADICCT-project (Assessing and Developing Initiatives of Companies to control and reduce Commuter Traffic) which is financed by Belgian Science Policy in the Science for a Sustainable Development research programme. We are also grateful to Grégory Vandenbulcke (UCL) and the FPS Mobility and Transport for delivering data and information.

\section{BIBLIOGRAPHY}

ABBES-ORABI F., DE WOLF N. (2007), “Assessing and Developing Initiatives of Companies to control and reduce Commuter Traffic (ADICCT). A literature review", Proceedings of Colloqium Vervoersplanologisch Speurwerk (CVS), De Xpert-factor, Antwerp, 22-23 November, pp. 137-153.

ANSELIN L. (1995), “Local Indicators of Spatial Association-LISA”, Geographical Analysis, 27, pp. 93-115.

ANSELIN L. (2002), "Under the hood - Issues in the specification and interpretation of spatial regression models", Agricultural Economics, 27, pp. 247-267.

ARAUZO-CAROD J.-M. (2008), "Industrial location at a local level : comments on the territorial level of the analysis", Tijdschrift voor Economische en Sociale Geografie, 99, 2, pp. 193-208.

BANISTER C., GALLENT N. (1999), “Sustainable commuting : A contradiction in terms ?”, Regional Studies, 33, 3, pp. 274-280. 
CAO X., MOKHTARIAN P. L. (2005), "How do individuals adapt their personal travel ? Objective and subjective influences on the consideration of travel-related strategies for San Francisco Bay Area commuters", Transport Policy, 12, 4, pp. 291-302.

CHEN C., H. GONG H. \& PAASWELL R. (2008), "Role of the build environment on mode choice decisions : Additional evidence on the impact of density", Transportation, 35, 3, pp. 285-299.

COMSIS CORPORATION (1993), A guidance manual for implementing effective employer-based travel demand management programs, Washington, The Institute of Transportation Engineers.

CUPPLES J., RIDLEY E. (2008), “Towards a heterogeneous environmental responsibility : sustainability and cycling fundamentalism”, Area, 40, 2, pp. 254-264.

DE WASSEIGE Y., LAFFUT M., RUYTERS C., SCHLEIPER P. (2000), Bassins d'emploi et régions fonctionnelles - méthodologie et définition des bassins d'emploi belges, Ministère de la Région wallonne, Service des Etudes et de la Statistique.

DICKINSON R. (1957), “The geography of commuting : the Netherlands and Belgium”, Geographical Review. 47, pp. 521-538

DICKINSON J.E., KINGHAM S., COPSEY S., PEARLMAN HOUGIE D.J. (2003), “Employer travel plans, cycling and gender : will travel plan measures improve the outlook for cycling to work in the UK ?", Transportation Research D, 8, 1, pp. 53-67.

FERGUSON E. (2000), Travel Demand Management and Public Policy, Ashgate, Aldershot, UK. GOLDSTEIN H. (1995), Multilevel Statistical Models. London, Arnold.

HEINEN E., VAN WEE B., MAAT K. (2008), "Het effect van werk gerelateerde aspecten op fietsgebruik voor woon-werkverkeer", Proceedings of Colloqium Vervoersplanologisch Speurwerk (CVS) , Santpoort, 20-21 november 2008.

KINGHAM S., DICKINSON J. \& COPSEY S. (2001), "Travelling to work : will people move out of their cars", Transport Policy, 8, pp. 151-160.

LANGFORD I. H., BENTHAM G., MCDONALD A.-L. (1998), "Multi-level modelling of geographically aggregated health data : a case study on malignant melanoma mortality and UV exposure in the European community", Statistics in Medicine, 17, pp. 41-57.

LUKE D. A. (2004), Multilevel modelling, Thousand Oaks, CA, Sage.

MAAS C.J.M. \& HOX J.J. (2004), "Robustness issues in multilevel regression analysis”, Statistica Neerlandica, 58, 2, pp. 127-137.

MARTENS K. (2004), “The bicycle as a feedering mode : experiences from three European countries", Transportation Research Part D, 9, pp. 281-294.

MEERSMAN H., PAUWELS T. \& VAN DE VOORDE E. (1998), “Bouwen aan een duurzame mobiliteit Het woon-werkverkeer in de Belgische bouwsector : situering, analyse en strategische alternatieven", Tijdschrift Vervoerswetenschap, 34, 4, pp. 361-377.

NAESS P. \& SANDBERG S.L. (1996), “Workplace location modal split and energy use for commuting trips”, Urban Studies, 33, 3, pp. 557-580.

O'FALLON C., SULLIVAN C. \& HENSHER D.A. (2004), “Constraints affecting mode choices by morning car commuters", Transport Policy, 11, pp. 17-29.

ORFORD S. (2000), “Modelling Spatial Structures in Local Housing Market Dynamics : A Multilevel Perspective”, Urban Studies, 37, 9, pp. 1643-1671. 
PARKIN J., RYLEY T. \& JONES T. (2007), "Barriers to cycling : an exploration of quantitative analyses”, in ROSEN P., HORTON D. \& COX P. (eds.), Cycling and Society , Ashgate, Aldershot, UK.

POTTER S., RYE T. \& SMITH M. (1999), “Tax and green transport plans : a survey of UK experience", Transport Policy, 6, 4, pp. 197-205.

RASBASH J., STEELE F., BROWNE W.J. \& PROSSER B. (2005), A user's guide to MLwiN version 2.0, University of Bristol.

RIETVELD P. \& DANIEL V. (2004), “Determinants of bicycle use : do municipal policies matter ?", Transportation Research Part A, 38, pp. 531-550.

RODRIGUEZ D.A. \& JOO J. (2004), “The relationship between non-motorized mode choice and the local physical environment”, Transportation Research D, 9, 2, pp. 151-173.

RYE T. (1999), "Employer attitudes to employer transport plans : a comparison of UK and Dutch experience”, Transport Policy, 6, 3, pp. 183-196.

SCHWANEN T., DIELEMAN F. M. \& DIJST M. (2004), "The impact of metropolitan structure on commute behavior in the Netherlands : A multilevel approach", Growth and Change, 35, 3, pp. 304-333.

SUBRAMANIAN S.V., DUNCAN C. \& JONES K. (2001), “Multilevel perspectives on modeling census data", Environment and Planning A, 33, pp. 399-417.

TRANMER M. \& STEEL D.G. (2001), "Ignoring a level in a multilevel model : evidence from UK census data", Environment and Planning A, 33, pp. 941-948.

VANDENBULCKE G., DUJARDIN C. \& THOMAS I. (2008), Cycling to work: Modelling spatial variations within Belgium, $48^{\text {th }}$ Congress of the European Regional Science Association (ERSA), Liverpool (UK), August 2008.

VANDENBULCKE G., THOMAS I., DE GEUS B., DEGRAEUWE B., TORFS R., MEEUSEN R., in PANIS L. (2009a), "Mapping bicycle use and the risk of accidents for commuters who cycle to work in Belgium", Transport Policy, 16, 2, pp. 77-87.

VANDENBULCKE G., DUJARDIN C., THOMAS I., DE GEUS B., DEGRAUEWE B., TORFS R., MEEUSEN R., in PANIS L. (2009b), Cycling to work: modelling meso-scale spatial variations within Belgium, Paper presented at the NECTAR conference, Washington (US), June 2009.

VAN MALDEREN L., JOURQUIN B., THOMAS I., VANOUTRIVE T., VERHETSEL A., WITLOX F. (2009), "Mobility policies of the companies located in Belgium : are there success stories", in MACHARIS C., TURCKSIN L. (eds.), Proceedings of the BIVEC-GIBET Transport Research Day 1, VUB Press, Brussels, pp. 559-578.

VANOUTRIVE T., PARENTI A. (2009), On proximity and hierarchy: exploring and modelling space using multilevel modelling and spatial econometrics, Paper presented at the $49^{\text {th }}$ European Congress of the Regional Science Association International (ERSA), Lodz (Poland), August 2009.

VERHETSEL A., THOMAS I., VAN HECKE E. \& BEELEN M. (2007), Pendel in België (Deel I), de woonwerkverplaatsingen, Statistics Belgium Working Paper.

ZAHRAN S., BRODY S.D., MAGHELAL P., PRELOG A., LACY M. (2008), “Cycling and walking : Explaining the spatial distribution of healthy modes of transportation in the United States", Transportation Research Part D, pp. 462-470. 


\section{ABSTRACTS}

The daily commute is still the main source of traffic congestion. Despite transport research emphasis on commuters, the work end of home to work travel receives less attention. However, employers influence the commute behaviour of employees in different ways. The Belgian database Home-to-Work-Traffic (HTWT) contains information on accessibility, work regimes and mobility management initiatives of 7460 worksites of large employers in Belgium. In a spatial multilevel regression model both contextual and worksite factors are incorporated to investigate the share of cycling employees. While controlling for different economic, physical and other factors, the provision of bicycles by the employer seems to be successful, while the effect of bicycle facilities is less clear, partly due to the fact that bicycle facilities are more popular in less cycle-friendly areas.

Het dagelijkse pendelverkeer is nog steeds de voornaamste bron van verkeerscongestie. Ondanks de nadruk die transportonderzoek legt op dit pendelverkeer, blijft de werkkant van het woonwerkverkeer onderbelicht. Nochtans beïnvloeden werkgevers het pendelgedrag van hun werknemers op verschillende manieren. De Belgische databank woon-werkverkeer bevat informatie over de bereikbaarheid, de arbeidstijden en mobility management maatregelen van 7460 werklocaties van grote werkgevers gevestigd in België. In een ruimtelijk multilevel regressiemodel zijn zowel omgevings- als werklocatiefactoren opgenomen om het aandeel fietsende werknemers te verklaren. Rekening houdend met economische, fysische en andere factoren, lijkt het actief aanbieden van fietsen door de werkgever een succesvolle maatregel, terwijl het effect van de klassieke fietsvoorzieningen minder duidelijk is, onder meer omdat deze vooral terug te vinden zijn in minder fietsvriendelijke gebieden.

\section{INDEX}

Keywords: bicycle, commuting, mobility management, Belgium, multilevel modelling motsclesnl fiets, woon-werkverkeer, België, multilevel modellen

\section{AUTHORS}

\section{THOMAS VANOUTRIVE}

Department of Transport and Regional Economics, University of Antwerp, Department of Geography, Ghent University, thomas.vanoutrive@ua.ac.be

\section{LAURENT VAN MALDEREN}

Facultés Universitaires Catholiques de Mons (FUCaM), Université catholique de Louvain

\section{BART JOURQUIN}

Facultés Universitaires Catholiques de Mons (FUCaM), bart.jourquin@fucam.ac.be

\section{ISABELLE THOMAS}

C.O.R.E., Université catholique de Louvain, isabelle.thomas@uclouvain.be 


\section{ANN VERHETSEL}

Department of Transport and Regional Economics, University of Antwerp, ann.verhetsel@ua.ac.be

\section{FRANK WITLOX}

Department of Geography, Ghent University, Frank.Witlox@UGent.be 